\title{
International Migration, Agency and Regional Development in Rural Europe
}

\author{
Michael Woods
}

Aberystwyth University. Department of Geography and Earth Sciences

m.woods@aber.ac.uk

Reception: January 2016

Acceptance: June 2016

\begin{abstract}
International migration to rural areas has become an increasingly important process in Europe, with the potential to act as a key driver of change in the localities concerned. Research has started to document patterns of international migration and the experiences of migrants, but this emergent body of literature is partial and fragmented between regionalscale studies focused on specific types of migration. This paper aims to construct a more holistic perspective by drawing on evidence from three research projects that collectively have examined multiple dimensions of migration in several case study regions across Europe. It distils overarching characteristics of contemporary international migration to rural areas that emphasize the complexity of migration processes and impacts and which challenge established perceptions of migration in rural areas. It then proceeds to focus on the impact of international migration for recipient localities and in particular considers the potential contribution of international migration to regional development.
\end{abstract}

Keywords: international migration; rural change; economic development; Europe

\section{Resum. Migració internacional, acció i desenvolupament regional a l'Europa rural}

La migració internacional a les zones rurals s'ha convertit en un procés cada vegada més important a Europa que adquireix el potencial d'actuar com a factor clau del canvi en els espais involucrats. Els primers resultats obtinguts fins ara documenten els patrons de la migració internacional i les experiències dels migrants, però aquest cos emergent de la literatura és parcial i fragmentada entre diversos estudis que, a diferents escales regionals, es focalitzen en alguns tipus específics de migració. Aquest treball té com a objectiu construir una perspectiva més holística a partir dels coneixements aportats per tres projectes d'investigació que col-lectivament han estudiat múltiples dimensions de la migració en diversos casos d'estudi europeus. S'aprecien característiques generals de la migració internacional contemporània a les zones rurals que denoten la complexitat dels processos migratoris i els seus impactes, i que posen en qüestió moltes de les percepcions preestablertes de la migració de les zones rurals. També es presenta quin és l'impacte de la migració internacional per a les localitats receptores $i$, en particular, es considera la contribució potencial que té aquesta migració internacional per al desenvolupament regional.

Paraules clau: migració internacional; canvi rural; desenvolupament econòmic; Europa 
Resumen. Migración internacional, acción y desarrollo regional en la Europa rural

La migración internacional a las zonas rurales se ha convertido en un proceso cada vez más importante en Europa, y adquiere el potencial de actuar como factor clave del cambio en los espacios involucrados. Los primeros resultados obtenidos a día de hoy documentan los patrones de la migración internacional y las experiencias de los migrantes, pero este cuerpo emergente de la literatura se presenta como parcial y fragmentado entre varios estudios que, a diferentes escalas regionales, se focalizan en algunos tipos específicos de migración. Este artículo tiene como objetivo construir una perspectiva más holística a partir de los conocimientos aportados por tres proyectos de investigación que de forma colectiva han profundizado en múltiples dimensiones de la migración en varios casos de estudio europeos. Los resultados permiten apreciar características generales de la migración internacional contemporánea en las zonas rurales que denotan la complejidad de los procesos migratorios y sus impactos, y que ponen en cuestión muchas de las percepciones preestablecidas de la migración a las zonas rurales. También se presenta cuál es el impacto de la migración internacional para las localidades receptoras y, en particular, se considera la contribución potencial que tiene esta migración internacional para el desarrollo regional.

Palabras clave: migración internacional; cambio rural; desarrollo económico; Europa

\section{Résumé. Migration internationale, action et développement régional dans l'Europe rurale}

La migration internationale vers les zones rurales est devenue un processus de plus en plus important en Europe, et présent un potentiel d'action comme facteur clé du changement dans les espaces concernés. Les premiers résultats obtenus à ce jour documentent les schémas de migration internationale et les expériences des migrants, mais ce corps émergent de la littérature est présenté comme partiel et fragmenté entre plusieurs études qui, à différentes échelles régionales, se concentrent sur certains types spécifiques de migration. Cet article vise à construire une perspective plus globale de la connaissance fournie par trois projets de recherche qui, collectivement, se sont penchés sur les multiples dimensions de la migration dans plusieurs études de cas européennes. Les résultats permettent d'évaluer les caractéristiques générales de la migration internationale contemporaine dans les zones rurales qui montrent la complexité des processus de migration et de leurs impacts, et qui remettent en question bon nombre des perceptions préexistantes de la migration vers les zones rurales. Il présente également l'impact des migrations internationales sur les communautés d'accueil et en particulier, il considère la contribution potentielle que cette migration internationale a pour le développement régional.

Mots-clés: migration internationale; changement rural; développement économique; Europe

\section{Summary}

\section{Introduction}

2. International migration and rural Europe: the existing literature

\section{Methods and sources}

4. The dynamics of international migration in rural Europe

5. Migration and regional development

6. Conclusion

Bibliographical references 


\section{Introduction}

Migration is a key driver of change in rural areas. Historically, for most of rural Europe over the last couple of centuries, the predominant trend has been out-migration and depopulation, with flows to industrial and urban centres depleting the population of rural areas, weakening their economies, and leaving a mark on the rural landscape in the form of abandoned farms and cottages. In the late twentieth century, however, evidence of a 'population turnaround' started to emerge, with migration from towns and cities to rural areas, especially by the middle classes. Whilst the prevalence of this trend may have been exaggerated in rural geography by the over-representation of Anglocentric research (Halfacree, 2008), many rural communities in most European nations have been touched by counterurbanization for at least a period in the last forty years (see Kontuly, 1998; Woods, 2005a), and in these communities in-migration has had a transformative impact. Not only has migration contributed to economic regeneration - both through the entrepreneurship of in-migrants and through the expansion of local markets - but it has also, more contentiously, inflated property prices and displaced local working class households in processes of gentrification, stoked environmental pressures with demands for more housing and infrastructure, diluted and marginalized local cultural traditions, and prompted local conflicts and power struggles (Bell, 1994; Murdoch and Marsden, 1994; Woods, 2005b). In many cases, pressures for change have resulted from differences in the perceptions of rurality held by established residents and in-migrants, with migrants' pursuit of the 'rural idyll' clashing with the more utilitarian discourses of established residents. In this way, migration can be seen to be forging a 'new rurality'.

Initially, at least, counterurbanization was primarily observed and understood as a domestic phenomenon, taking place within the delimited space of the nation state. As we have moved into the twenty-first century, however, a further shift in the demography of rural Europe has become apparent with the increasing significance of transnational migration. To some extent, international migration into rural areas in Europe represents an extension of domestic counterurbanization, as lifestyle or amenity migrants from cities such as London have elected to pursue the rural idyll not by moving to domestic destinations such as the south-west of England, but by moving to arcadian parts of France, Italy or Spain. In contrast to domestic counterurbanization, though, this middle class migration has been complemented by an equally significant strand of transnational labour migration, much of which has targeted rural labour market shortages in low-paid jobs, such as agricultural field work. The rise of transnational migration across Europe has been facilitated in large part by the liberalization of movement and standardization of employment rights within the European Union, with labour migration in particular jumping in scale with the enlargement of the EU to central and eastern Europe in 2004; but it has also been assisted by the expansion of budget airline operations and by improved communication networks, and parallels can be observed outside 
Europe, for example in Latino labour migration the rural south and west of the United States (Nelson and Hiemstra, 2008; Nelson and Nelson 2011; Smith and Furuseth, 2006), or in lifestyle migration from North America to selected rural areas of central and south America (Martarrita-Cascante and Stocks, 2013; Martarrita-Cascante et al., 2015; Moss, 2006; Rainer, 2016; Truly, 2002).

In Europe, the growth of international migration to rural regions has been documented by a burgeoning literature, as reviewed in more detail below, but as studies have tended to be only regional or national in scope and focused on one type of migration, the emerging overall picture remains fragmented. This paper aims to construct a more holistic perspective by drawing together evidence from three different research projects, conducted between 2006 and 2015, which collectively have involved empirical research in six European countries and across different categories of migrant, including labour migrants, lifestyle migrants, return migrants, cross-border commuters and refugees. The detailed results of each of these studies can be found elsewhere (see Farrell et al., 2012; Jones and Lever, 2014; McDonagh et al. 2015; Lampič and Mrak, 2012; Nadler, 2012; Nienaber and Frys, 2012; Woods, 2011a; Woods, forthcoming; Woods and Watkin, 2008), with the discussion here focusing firstly on the key overarching trends and dynamics that emerge from the data, and secondly on the transformative capacity of international migration, and particularly its contribution to regional development.

\section{International migration and rural Europe: the existing literature}

Until recently, research on international migration primarily focused on urban areas. In spite of the extensive research on domestic migration to rural regions in Britain, North America and parts of Europe, and a similarly extensive body of research on out-migration from rural regions elsewhere, including emigration, the possibility and reality of international migration to rural areas was largely neglected, reflecting the broader 'invisibility' of international migrants in rural communities. Only in the last decade has significant research started to be conducted and published that has challenged stereotypes in documenting the extent and particularities of international migration to rural regions. In particular, a number of studies have examined the experience of Latino migrants in the rural United States, noting the deconcentration of Latino migrants away from border regions into wider areas of the South, West and Mid West, and the contribution of migrants in reshaping rural communities (e.g. Nelson and Hiemstra, 2008; Nelson and Nelson, 2011; Smith and Furuseth, 2006). In Europe, interest in international migration to rural regions was stimulated by the significant movement of migrant workers from Central and Eastern Europe, notably Poland, to rural regions in Britain, Ireland, Norway, Sweden and Iceland, especially following the enlargement of the European Union in 2004 (Findlay and McCollum, 2013; Hedberg et al., 2012; Jentsch et al., 2007; McAreavey, 2012; 
Rogaly, 2008; Rye and Andrzejewska, 2009; Skaptadóttir and Wojtynska, 2008), supplementing individual studies that had already examined more established patterns of labour migration from North Africa to rural Spain and Portugal (Camarero et al., 2012; Fonesca, 2008; Hoggart and Mendoza, 1999) and from the Balkans to rural Greece (Kasimis 2008; Kasimis et al., 2003, 2010; Labrianidis and Sykas, 2009; Papadopoulos, 2012), as well as more longdistance migration relationships, including those from Latin America to rural Portugal and Spain (Fonesca, 2008; Moren-Algeret, 2008) and from Thailand to rural Sweden (Hedberg and Haandrikman, 2014).

Separate but parallel to the literature on rural labour migration has been a body of research on international amenity or lifestyle migration to parts of rural Europe, including studies of both full-time migration and seasonal second home residence notably by affluent Britons, Germans and Dutch in parts of France, Italy, Portugal, Spain and Sweden (Benson, 2013; do Carmo and Santos, 2012; Eimermann et al., 2012; Fonesca, 2008; Gallent and Tewdwr-Jones, 2000; Hedberg and Haandrikman, 2014; Moren-Algeret, 2008); and research on retirement migration, including that by British retirees to the Mediterranean, which frequently involves a combination of lifestyle and financial motivations (King et al., 2000; Warnes and Williams, 2006). The less voluntary migration of asylum seekers or refugees has been noted by Hubbard (2005) in the context of rural opposition to asylum processing centres in England; while more individual migrant stories have been recorded in studies of ethnicity in rural areas and instances of rural racism (Chakraborti and Garland, 2004; Neal, 2009).

Whilst still evolving, the literature on international migration to rural regions is now substantial enough to provide evidence for a critique of some established assumptions about migration. Not only does it demonstrate that immigration and multiculturalism are not exclusively urban phenomena, but it also suggests that patterns and processes of contemporary migration are more fluid and dynamic than often imagined, and are situated within a matrix of stretched translocal social relations. Skaptadóttir and Wojtynska's (2008) study of Polish migrant workers in Icelandic coastal communities, for example, reveals the rural communities to be transnational spaces in which hybrid cultural identities are articulated and negotiated, but also describes the continuing embeddedness of migrants in social networks of their home communities, thus living 'bifocal lives', "working in Iceland to create a better life back home" (p. 124). Such accounts challenge conventional notions of migration as a linear relocation from $\mathrm{A}$ to $\mathrm{B}$.

From this perspective we can articulate an alternative rendering of international migration as just one expression of an intensified and accelerated global mobility of people, forming one part of a greater whole that encompasses the diurnal movement of commuters, tourists, business travellers and transport workers, weekend residents and holiday-home owners, short-term labour migrants, forced migrants, elective travellers, and intending permanent settlers (see also Halfacree, 2012). These mobile people move to, from and 
through rural areas, forming diverse and often transitory attachments, without necessarily jettisoning the attachments that they have accumulated in different places. As such, mobile people are facilitators for the mobility of things, ideas and practices, and accordingly are agents of hybridization: unavoidably changing the places that they inhabit.

Yet the majority of research to date on international migration to rural Europe has tended to focus on the migrants themselves, their structural context and their experiences, rather than on the impacts of international migration on the localities to which they have moved. Thus, for example, research has explored the motivations and aspirations of migrants (King et al, 2000; Moren-Algeret, 2008; Stenbacka, 2012), the structural conditions of their employment, especially in agriculture (Findlay and McCollom, 2013; Hoggart and Mendoza, 1999; Rogaly, 2008; Rye and Andrzejewska, 2009; Scott, 2015), their inter-personal relations and interactions with the local community (Camarero et al., 2012; do Carmo and Santos, 2012; Jentsch et al., 2007; McAreavey, 2012; Moren-Algeret, 2008), and their negotiation of multiple and fluid identities (de Lima, 2012; McAreavey, 2012; Skaptadottir and Wotjynska, 2008). Taken together, these analyses communicate mixed messages about the agency of migrants: some emphasizing the structural disempowerment of migrants as marginalized individuals who are acted on; others emphasizing the agency of individual migrants to construct their own identities and futures. The agency of migrants to re-shape the places in which they live, however, is much less commonly considered (exceptions include Bayona i Carrasco and Gil-Alonso, 2013; Hedberg et al., 2012; Kasimis et al, 2010; and Moren-Algeret, 2008). This oversight contrasts with the much larger literature on domestic migration to rural areas, which some time ago moved beyond merely attempting to quantify and map migration patterns or to understand migrant motivations to investigate the consequences of significant in-migration for rural communities, including the contribution to economic development (see for example, Kilpatrick et al (2011) and Stockdale (2006)).

The discussion that follows in this paper seeks to at least partially address this shortcoming by considering questions of structure and agency, both in relation to the dynamics of international migration to rural areas, and with regard to the impacts of international migration in rural localities and particularly, including through economic development and cultural influence.

\section{Methods and sources}

The remaining discussion in this paper draws on three research projects conducted between 2006 and 2015, in which I have been involved, and which between them have examined aspects of international migration in different parts of rural Europe (see figure 1). The first project, DERREG (Developing Europe's Rural Regions in an Era of Globalization), was funded by the European Union's Framework Programme 7 and examined rural development in Europe in the context of globalization. The discussion here draws on a 
work package that focused on international migrants and mobility, involving contextual analysis across ten regions, primarily using published statistics and documents that provided an insight into the broad patterns of migration flows, and detailed case study research by consortium partners in six regions: Alytus county (Lithuania), Oberlausitz (Germany), Ovre Norrland (Sweden), Pomurska (Slovenia), Saarland (Germany), and County Roscommon (Ireland). ${ }^{1}$ A total of 113 qualitative interviews with migrants were conducted by researchers from the partner institutions across these case study regions between November 2009 and April 2010, including 50 with migrant workers (in Alytus, Dresden, Övre Norrland and Saarland), 39 with foreign homeowners (in Övre Norrland, Pomurska and Saarland), and 24 with return migrants (in Alytus and County Roscommon), as well as interviews with municipal leaders in two of the regions (Alytus and Pomurska) (for more details of the research see Farrell et al., 2012; McDonagh et al. 2015; Kairyte, 2015; Lampič and Mrak, 2012; Lampič et al., 2015; Nadler, 2012; Nienaber and Frys, 2012, 2015).

The second project, GLOBAL-RURAL, is an ongoing grant funded by the European Research Council concerned with exploring how rural localities are being re-made through engagement with globalization processes, involving case studies in several parts of the world focused on different dimensions of globalization. The discussion in this paper draws particularly on one case study of international migration in two rural small towns in Ireland: Ballyhaunis in County Mayo, and Gort in County Galway. The research, undertaken by the author, involved ten interviews with migrants and key community members in the two towns conducted in October 2015, supplemented by ethnographic observation and data from press articles and previous published and unpublished reports and studies (including Healey 2006; Maher, 2010; McGrath, 2010; McGrath and McGarry, 2014; Sheringham, 2009, 2010). ${ }^{2}$

The third source for the paper is research conducted by the Wales Rural Observatory for the Welsh Government in two studies of central and eastern Europe migrant workers (predominantly Polish) in Wales. The first study, undertaken in 2006 and 2007, involved statistical analysis of migrant worker registrations between 2004 and 2006 across the whole of Wales, interviews with 15 key stakeholders, and 100 structured questionnaire interviews with

1. DERREG was co-ordinated by the author, with the migration work package designed and led by Birte Nienaber at Universität des Saarlandes and research in the case study regions conducted by Birte Nienaber and Wioletta Frys (Universität des Saarlandes) (Saarland); Robert Nadler, Michael Kirszan and Joachim Burdack (Leibniz-Institut für Länderkunde) (Oberlausitz); Emilija Kairyte (NeVork) (Alytus); Petri Kahila, Moa Hedström and Andrew Copus (Nordregio) (Övre Norrland); Maura Farrell, Marie Mahon and John McDonagh (National University of Ireland, Galway) (County Roscommon); and Barbara Lampič and Irena Mrak (University of Ljubljana) (Pomurska).

2. For more information on the GLOBAL-RURAL research see <http://globalruralproject. wordpress.com>. 
migrant workers in four case study areas: Betws-y-Coed and Llanrwst in north Wales; Milford Haven and Haverfordwest in west Wales; Ceredigion and northern Carmarthenshire in west Wales; and Welshpool in mid Wales (25 interviews in each case study). ${ }^{3}$ The follow-up study, undertaken between May 2012 and October 2013, repeated the methodological strategy, with an updated statistical analysis, key stakeholder interviews, and 109 structured questionnaire interviews with migrant workers in two rural case study areas - Conwy, Anglesey and Gwynedd in north Wales, and Welshpool in mid Wales - one mixed rural and urban case study - Carmarthenshire in southwest Wales - and one urban case study - Merthyr Tydfil in south Wales (for more details of the research see Jones and Lever, 2014; Woods, $2011 \mathrm{a}$; Woods and Watkin, 2008). ${ }^{4}$

Together, these three studies have collated a significant volume of qualitative and quantitative data relating to international migrants with varying backgrounds and motivations in a number of different parts of Europe. However, as the studies were designed and implemented independently, with different objectives and research questions, and involved different methodologies for data collection, including different sampling or recruitment strategies and different approaches to interviewing, caution should be taken in considering the resulting material as a single, coherent dataset. Rather, it is more appropriate to focus on the interpretation and analysis resulting from these studies. As such, the narrative outlined in this paper takes the form of a meta-analysis that involved the close reading and coding of the data interpretation and analysis from the three studies presented in publications and internal working documents in order to identify recurrent or complementary themes, with reference back to the original data where appropriate for verification and illustration. Accordingly the discussion in this paper emphasizes trends and tendencies, but does not attempt to quantify these.

The international migrants examined in the three studies include individuals who could be variously categorised as economic migrants, labour migrants, lifestyle or amenity migrants, retirement migrants, return migrants, refugees or asylum seekers, and so on. While these categories have been commonly used in the existing literature, they have also contributed to the fragmentation of research on international migrants in rural localities, often artificially. Indeed, the evidence from the three studies suggests that the categories are blurred at best, with individuals straddling boundaries: many of the Polish 'migrant workers' studied in Wales by the WRO, for example, also expressed lifestyle or cultural motivations for their move as well as economic reasons; while the

3. The 2007 WRO study was led by the author, with data collection by Catherine Walkley, Eliza Bednarek and Magdalena Markham, and analytical input by Jonathan Radcliffe and Suzie Watkin.

4. Research for the 2013 WRO study was undertaken by Laura Jones and John Lever, with design and analytical input by the author, data collection support by Magdalena Markham, and statistical analysis by Jonathan Radcliffe. The study was a collaboration between the Universities of Aberystwyth and Cardiff. 


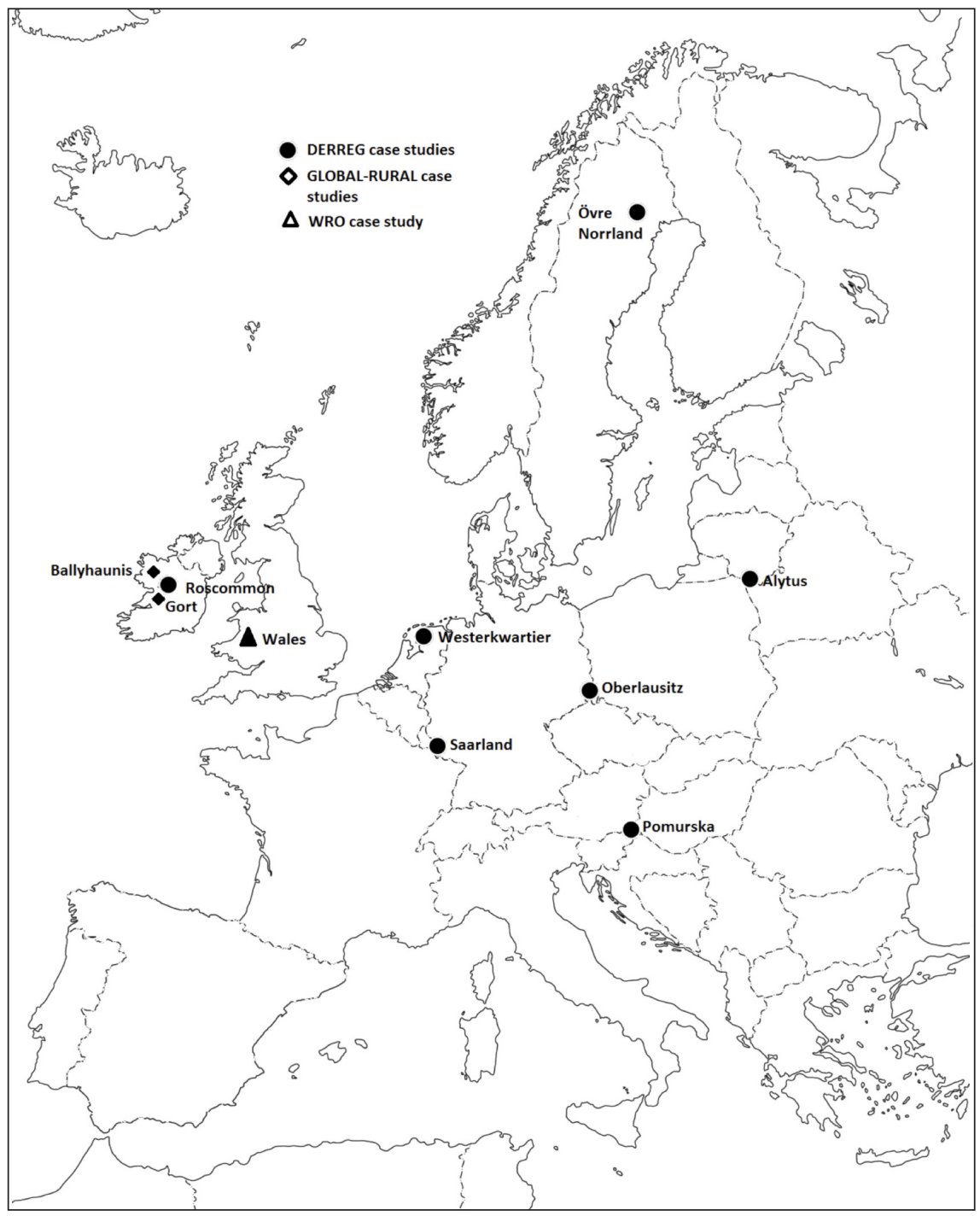

Figure 1. Location of case studies referred to in the paper.

Source: author's own elaboration.

British 'amenity migrants' in Slovenia studied by DERREG cited economic as well as lifestyle rationales for their relocation. Furthermore, the meta-analysis revealed similar patterns and experiences across the different groups. As such, the observations presented in the following sections refer to all international migrants, unless specified. 


\section{The dynamics of international migration in rural Europe}

Data from the DERREG, GLOBAL-RURAL and Wales Rural Observatory (WRO) research collectively provides evidence of the reach of international mobility throughout rural Europe, but also of its deceptiveness. At first glance, the broad scale analyses of Census and other population data by DERREG and the WRO both superficially seem to reinforce popular perceptions of rural regions as largely ethnically and culturally homogenous populations, with immigration more strongly concentrated in urban regions in both absolute and relative terms. Yet further excavation reveals the presence of small, but notable, migrant communities in each of the localities studied. Some of these reflected well-known migration patterns, such as Polish and Lithuanian migrant workers in Ireland and Wales, or German second home owners in Sweden; but others are less well documented, including British amenity migrants in Slovenia and Thai seasonal workers in Sweden.

Moreover, reducing the scale down to the community level identifies unexpected enclaves of substantial migrant populations that are invisible when analysis is conducted at the larger regional scale: the municipality of Perl, in Saarland, where a quarter of the population have moved across the border from Luxembourg; the village of Llanybydder in west Wales, with up to 200 Polish migrant workers living in a population of around 1,500 people and working at a local abattoir; and, most strikingly, the two Irish towns of Ballyhaunis and Gort. Ballyhaunis is described as the most diverse town in Ireland, with the 2011 Census recording 43 different nationalities in its population of 2,312 people, with 48 per cent of residents born outside Ireland. These include migrants from Pakistan and Syria who were recruited to work in a halal meat processing plant in the 1970s and 1980s; migrant workers from Poland, Lithuania and other countries of central and eastern Europe who arrived following EU enlargement in 2004; and refugees resident at an asylum reception centre in the town, as well as former refugees who elected to settle in Ballyhaunis, including individuals from Afghanistan, Eritrea, Nigeria and Russia. Gort is known for the Brazilian migrants who were first recruited to work in a local abattoir in the late 1990s and subsequently moved into a range of other occupations. At its peak in 2008, the Brazilian community numbered over 1,000 individuals in a town population of around 2,700 people, but has since shrunk to around 300 remaining Brazilian residents in 2015.

Behind these statistics are a multitude of individual stories of global mobilities, some of which have been captured by the qualitative interviews conducted for the studies. By comparing and synthesizing the findings from each of the studies, individual stories can be amalgamated into broader narratives, pointing to a number of key observations.

Firstly, the pervasiveness of international migration through rural Europe is disguised by the relative invisibility of migrants within rural communities. In contrast to the visible concentrations of ethnic communities in urban neighbourhoods, international migrants in rural areas are much fewer in number, 
and more likely to be dispersed across wider territories. For example, between 2004 and 2010, over 650 properties in the Slovenia region of Pomurska were bought by foreign purchasers, mostly British, yet these properties were dispersed among different villages, such that the signs of a British or foreign presence in any one individual village is muted. Even where migrant groups are more geographically concentrated there can be limited visible evidence of their communities. The onion-dome of the mosque constructed by the Muslim community in Ballyhaunis is an unexpected sight in a small Irish town, but it is unobtrusively positioned behind a factory car park, and there are few other signs of the town's multicultural population - a halal food shop, an Indian and Eastern European take-away - with the high street still appearing much the same as that of any other rural town in Ireland, dominated by established local businesses and cultural tastes. Similarly, in Gort and Roscommon, a smattering of Polish and Brazilian food shops, money transfer services, and Brazilian evangelical churches have appeared, but remain comparatively inconspicuous in the townscape. These elusive landscapes perhaps suggest a European equivalent of the 'silent bargain' observed by Torres et al. (2006) in the southern United States, whereby Latino migrants accepted a shadowy, marginal existence in rural communities in return for relative freedom from harassment and conflict (see also Winders 2007, 2012).

Secondly, although international migrants can be found across all the regions studied, the origins and types of international migration evident in different regions varies, and is strongly shaped by geography and history. In broad terms, this is reflected in the balance of migrants attracted to a region for lifestyle or economic reasons: lifestyle or amenity migration tends to be associated with regions that exhibit mountainous, arcadian or coastal landscapes, while labour migration tends to concentrate in localities that combine relative prosperity with labour-intensive industries such as horticulture. There are, however, also more nuanced relationships, especially around forms of geographical and cultural proximity.

In some cases, geographical proximity is still important - Luxembourgers relocating across the border to Germany while continuing to work in Luxembourg, for example; but many other instances, geographical proximity is less important in explaining migration flows than cultural proximity, including language and (post-)colonial histories. The previous residences of return migrants interviewed in Ireland for DERREG - in Britain, Canada and the United States - illustrates this, but so does the story of the South Malouccans in the Westerkwartier region of the Netherlands. ${ }^{5}$ People from a former Dutch colony in the south east Asian archipelago, the first of the community arrived as refugees from political violence after independence in the 1950s. More recently, around a further 1,500 individuals moved directly into the Westerk-

5. Westerkwartier, near Groningen in the northern Netherlands, was a case study region examined in the initial contextual analysis for DERREG but not included in the detailed migration research. 
wartier from the South Malouccan Islands between 2000 and 2003, escaping inter-communal unrest by joining the expatriate community that had become established in the villages around the original reception camp. Yet apparent historical connections can sometimes be misleading: the WRO research found that contemporary Polish migrants in rural Wales have little contact with a previous generation of Poles who settled in the region after the Second World War; while tensions were reported in Ballyhaunis between the established Syrian community that arrived in the 1980s and 1990s and some of the more recent refugees at the asylum reception centre.

Thirdly, the particular geographies of international mobility in the countryside are also dependent on catalysts that create opportunities around particular groups and regions. Catalysts can be events, such as the accession of countries in Central and Eastern Europe to the European Union in 2004, but particularly interesting is the role that individuals can play as catalysts connecting specific migrant groups with specific localities (a role also noted by Mountz and Wright, 1996, with respect to Mexican migration to the United States). The presence of British migrants in Pomurska, for example, is in part attributable to the initiative of an early British émigré, married to a Slovenian woman, who in anticipation of Slovenian entry to the EU in 2004 started to systematically buy and renovate dilapidated houses in the region, marketed them in Britain as idyllic lifestyle-investments, and provided services to assist with the process of moving and settling in Slovenia (see also Lampič and Mrak, 2012). Similarly, the Brazilian community in Gort, Ireland, is the result of entrepreneurial initiative by an Irish ex-patriate in Brazil who, noting a labour shortage in the meat-processing industry in Ireland, set himself up as an agent recruiting skilled workers from a Brazilian town where a large abattoir had recently closed to work in plants in Gort and Roscommon; while the Muslim population in Ballyhaunis owes its presence to a Pakistan-born, London-based trader who was approached by the Kuwaiti government in the late 1960s to set up a secure supply of halal meat and who, after considering several options, bought-out a local family-owned meat plant in the town.

Fourthly, even in relatively small communities, international migrants are not a homogeneous group, but exhibit differing motivations, experiences and aspirations. For example, the WRO research in Wales categorized Polish migrant workers into three cohorts: 'gap-year students', who were young people spending a short period abroad before, during or after education primarily to learn English and experience a different culture; 'neo-guestworkers', migrant workers primarily motivated by earning money, often sending remittances home and intending to return to Poland, but commonly spending repeated spells of working in different locations abroad; and 'settlers', migrants who intended to stay in Wales long term, and whose selection of a rural locality reflected preference for rural life as much as employment opportunities. These different motivations influenced their choice of work, and the micro-geography of their distribution. Among the WRO case studies, 'gap-year students' were disproportionately found in the tourism village of Betws-y-Coed and 
'neo-guestworkers' in the port town of Milford Haven, whilst 'settlers' were more widely spread through the region. These variegated patterns in turn affected how Polish migration was experienced in the individual communities concerned (see Woods and Watkin, 2008; Woods, 2011a). While the same categorization was not applied in the other studies, similar differentiations within migrant groups were observed. In Ballyhaunis, for instance, cleavages were identified not only been economic migrants and refugees, but also between Pakistani immigrants specifically recruited by a local employer in the 1980s and Eastern European migrant workers who arrived after 2004, often with more transitory intentions, as well as between Syrian economic migrants employed in meat-processing and more recent refugees from Syria resident in the asylum reception centre.

Fifthly, migrants' experiences of integration with the local community vary between localities and regions, reflecting the differing outlook of both migrants and established local residents. Overall, the international migrants interviewed for the three studies were positive about their situation, and few reported direct experiences of discrimination or harassment. Yet many described challenges adjusting to a new country and difficulties of integration, including return migrants in Ireland and Lithuania who recounted the 'claustrophobia' of moving back close to families or the disappointment of discovering that they had drifted apart from old friends with whom they had superficially maintained contact whilst away (see Farrell et al., 2012; also Ni Laoire, 2007). In Slovenia, migrants appeared to be welcomed by local communities for reoccupying empty properties and contributing to community activities, but migrants in eastern Saxony in Germany were more likely to described experiences of discrimination and marginalization, reflecting the suspicious attitude of residents in a post-industrial district with high levels of unemployment and notable activity by right-wing political groups (see Nadler, 2012). One recalled how an offer to volunteer his professional skills as an architect to a community hall project had been rebuffed, whilst another characterized his life in the rural town of Zittau as a 'zero-point experience' [Nullpunkterfahrung]:

Zittau as zero-point experience: this means, everything that you have learnt so far you have to give up more and more, you have to distance yourself from the structures of the developed understanding. Then you could experience this absolute zero-point experience. Only then you could learn and develop totally new structures, and only then you can feel at ease here. (Migrant worker, Dresden region) ${ }^{6}$

Sixthly, the mobility of international migrants through the global countryside is multi-directional and temporally contingent. Certain catalysts can prompt waves of migration, such as the enlargement of the European Union,

6. Interview conducted by Robert Nadler from IfL, Leipzig, for the DERREG project. See Nadler (2012). 
or the significance of civil unrest in the South Malouccan Island in driving refugees to the Netherlands. However, these waves fade and can be reversed as situations change. The economic recession since 2008 has, in particular, had a moderating impact on mobility flows in Europe. This has been most evident in the decreasing number of migrant workers from Eastern Europe in rural districts of Ireland and Wales as employment opportunities have diminished, but return migration to rural Ireland has also stalled and even reversed, and some British home-owners in Slovenia have sold up and returned home as their financial resources have been squeezed. ${ }^{7}$ Other changes in trends have had more specific turning points: in 2009 the meat-processing plant in Gort that had recruited Brazilian workers closed following a fire and did not re-open, and although Brazilians in the town were already employed in different sectors, it started a curve of decline that resulted in the majority of the migrants either returning to Brazil or moving elsewhere within Ireland. Yet these reversals are rarely comprehensive: there are still Polish and Lithuanian workers in Britain and Ireland; British amenity migrants in Slovenia; and Brazilian migrants in Gort. Nor do they recede over the same route. Few of the migrant workers who have left the rural region of Alytus in Lithuania since 2004 have returned home, even if they have moved on from the regions that they initially moved to. Those migrants who have returned - often reluctantly for health or family reasons - have frequently failed to settle, thus setting up a dominant trend of repeat emigration (see also Kairyte, 2015).

\section{Migration and regional development}

The re-presentation of international migration as an expression of a fluid global mobility has implications for strategies for regional development. In contrast to some articulations of endogenous development theory, it suggests that human capital should not be conceived of as a static internal resource that needs to be trained up to compete in a global economy, but rather can be positioned as a mobile resource that needs to be attracted, captured, retained and nurtured. However, the evidence of the discussed research is that harnessing of the economic potential of international migrants has been fragmented and limited at best.

In most cases, international migrants are primarily seen as stop-gap labour, recruited to fill particular areas of shortage in rural labour markets. Some of these gaps have arisen as a consequence of economic growth, with better overall employment opportunities for the local workforce creating shortages in lowergrade, lower-paid and often noxious occupations such as meat-processing and agricultural field work. These gaps have consequently been filled by interna-

7. The referendum vote in the UK in June 2016 to leave the European Union could also serve as a catalyst for substantial changes in the number and distribution of both labour migrants to the UK and lifestyle migrants from the UK to other parts of the EU, however the details of future relations between the UK an EU and thus the likely impact on migration and existing migrant communities were uncertain at the time of writing. 
tional migrants, including Brazilian and Polish abattoir workers in Ireland and Wales, and Thai seasonal workers harvesting berries in northern Sweden, echoing long-established and well-documented patterns in the United States (see for example Bodvarsson and Van Den Berg, 2003; Broadway, 1994; Cravey, 1997; Zúniga and Herández-León, 2006). Others reflect the difficulty in recruiting to certain professional positions in remoter rural regions, especially in healthcare, which in turn are filled by international migrants, possibly as a perceived career stepping-stone to a more prestigious position elsewhere. Collectively, these two trends have meant that significant parts of traditional rural society have become in effect internationalized in many regions. Not only are traditional rural industries such as farming and meat-processing dependent in some regions on international migrant workers, but international migrants can also occupy traditional positions of authority in rural communities such as doctors and dentists.

The majority of international migrants studied in the DERREG, GLOBAL-RURAL and WRO case studies are skilled or educated individuals. For some, including doctors, dentists and skilled abattoir workers, their qualifications, training or expertise have provided the passport to international mobility. Yet evidence suggests that large numbers of international migrants in rural regions are not working in occupations that match their qualifications or training. This was demonstrated in the WRO research on Polish migrant workers in rural Wales, which found that around half of the migrants surveyed held jobs that did not match their qualifications or training, and around half of these had tried unsuccessfully to find more appropriate employment (Woods, 2011a). Similar experiences were recounted by migrant workers interviewed in Saarland for DERREG, although many reported dissatisfaction with their employment situation in their home country and were relatively content with the jobs found in Germany (see Nienaber and Frys, 2012).

The reasons for these discrepancies are in part structural, and in part cultural. Opportunities for employment in previous careers and professions may be limited for international migrants to rural regions because of the relatively small scale of rural regional economies, with a limited range of industries and a restricted number of positions in certain professions (these constraints have also been observed in domestic migration, see for example Gärtner, 2016, Lolos and Papapetrou, 2012, Maza and Villaverde, 2004, and Mouhoud and Oudinet, 2010). At the same time, cultural barriers can exist in the form of language skills, the transferability of qualifications, lack of knowledge of local job markets, and implicit discrimination by employers. Migrant workers in Saarland, for example, emphasized that finding employment required a combination of personal determination, flexibility and use of social networks developed with the local community (see also Nienaber and Frys, 2012):

For me, it was a bit difficult at that time [for the search of employment] because I could not speak German properly. [...] I have worked for half a year until the company went bankrupt. [...] For me, the second and third year was 
exhausting, because several times I worked for temporary-employment agencies and $[\ldots]$ there you feel like a second-class citizen. (Migrant worker, Saarland) ${ }^{8}$

One regional development response to globalization is therefore to target the development of industries that can provide appropriate opportunities for international migrants. Although earlier incarnations of regional development policy focused on inward investment had been criticized in some regions for creating jobs for domestic in-migrants rather than for local residents (see Woods, 2011b), there is evidence that, for example, international return migration to Ireland was strongly correlated with the boom of the 'Celtic Tiger' economy in part because foreign direct investment created technical, managerial and professional positions that had not existed previously in rural districts. In the Alytus region of Lithuania, in contrast, the tendency for return migrants to become repeat emigrants reflects the limited development of the regional economy and the difficulty of finding employment that could compete in status and pay with jobs held abroad.

An alternative strategy is to promote entrepreneurship among international migrants. A significant proportion of the international migrants interviewed for DERREG were self-employed, including nearly half of the return migrants to rural Ireland. Entrepreneurship appears to be particularly significant for return migrants and amenity migrants, in part because these individuals tend to have available capital to invest in both property and a business start-up, and in part because self-employment provides flexibility that enables a move to be made for lifestyle or family reasons. In several cases, businesses were established by migrants that primarily traded internationally or in their previous country, commonly via the internet, such that the extent to which they formed a proper part of the regional economy of the district to which they had moved is questionable. In other cases, however, businesses were established that operated within the new locality. Three of the migrant workers interviewed in Saarland, for example, had set up catering businesses. In some cases, the new businesses were breaks away from previous careers, but in several instances they utilized skills and qualifications gained through emigration in previous residences, as one return migrant to Ireland explained (see also Farrell et al., 2012):

I returned to Ireland as a qualified plumber and set up my own business in addition to running the farm. I trained and obtained all my skills in Boston and without a doubt the training helped me gain employment contracts once I came home. (Return migrant, West of Ireland) ${ }^{9}$

Migrant workers can also become entrepreneurs, especially if opportunities to progress to more professional or skilled employment are limited. In

8. Interview conducted by Wioletta Frys at Universität des Saarlandes for DERREG. See Nienaber and Frys 2012.

9. Interview conducted by Maura Farrell at NUI Galway for DERREG. See Farrell et al. (2012). 
Ballyhaunis, for example, a Syrian family that originally came to work in the halal meat plant subsequently established their own company making halal sausage casings, which is now itself a significant employer in the town; whilst other migrants have opened businesses included halal food shops. These latter cases are examples of migrant entrepreneurs responding to needs in the migrant community - which may be particularly apparent in rural communities where, for example, the availability of ethnic food may be more restricted than in cities and is also evident in the Brazilian hairdressers, food shop, internet café and money transfer office in Gort, and the Polish shops in Ireland and Wales (see also Jones and Lever, 2014).

However, migrant entrepreneurs also frequently described problems navigating local bureaucracies and a perceived lack of support to assist them with establishing businesses (see also Hedberg et al., 2012). The majority of self-employed return migrants interviewed in Ireland, for example, were unsure about the availability of funding schemes for start-up businesses and of mentoring programmes, or were uncertain of their eligibility for such support - although one interviewee had successfully obtained financial assistance from the Roscommon LEADER Company to set up a recording business and mentoring from the Roscommon Enterprise Board. More broadly, initiatives explicitly designed to encourage and support entrepreneurship by international migrants in rural regions are limited in number, although there are some notable examples. These include a scheme run by the Strukturum local development company in the municipality of Jokkmokk in Övre Norrland, Sweden, which has received public funding to work with international migrants providing individual advice on starting businesses and support for newly established businesses.

The potential for international migrants to contribute to rural regional development is not restricted to in-migrants. Another strand of the DERREG project emphasized the importance to sustainable and resilient rural development of international networking by endogenous rural businesses, and the role played by 'network brokers' in facilitating this (see Copus et al., 2011). While in the cases studied 'network brokers' tended to be institutional actors, there is potential for emigrants from rural regions to act as informal network brokers in connecting businesses in their region to new partners and market opportunities abroad. This bridging role has been observed with respect to migrants from some communities in the global south. Aguayo (2008), for example, describes how the transformation of the traditional Quichua weaving industry in Otavalo, Ecuador, into an internationalized operation supplying 'ethnic product' markets globally was facilitated by the diasporic network of migrants from the region who had settled in cities across South America, the United States and Europe. Rural regions in Europe seem to be less attuned to capitalizing on the international networks of out-migrants, although the research suggests some signs of this changing. For instance, some businesses in Alytus, Lithuania - where international networking by enterprises is comparatively low due to structural constraints and a lack of language skills and international knowledge - described 
how they were starting to develop international linkages through Lithuanian migrants who had moved to other parts of Europe.

Yet if migrant businesses are aimed primarily at serving migrant populations, or if amenity migrants support themselves as self-employed traders or consultants working over the internet in their home country, the insularity of migrants may be reinforced and the contribution to the local economy may be limited. As such, the effective contribution of migration to economic development also requires social and cultural integration. Here again, the evidence from the three studies is mixed. Lifestyle migrants in Slovenia, on the one hand, commonly claimed to be well integrated in the local community, although they also admitted to language obstacles; on the other hand, Polish migrant workers in Wales reported limited involvement in the community, with only one in ten migrant workers surveyed by the WRO in 2007 participating in any organized activity, and a third commenting that all their friends in Wales were Polish. Yet the majority of those surveyed also agreed with the statement that they knew many people in the area, and four in ten said that they felt a sense of community with other people living in the local area (see also Woods and Watkin, 2008).

The complexity of migrant integration in rural communities was also captured in the GLOBAL-RURAL research in Ballyhaunis and Gort. Both towns have been presented as examples of good community integration, relations between migrant and Irish residents are good, and there is genuine interaction between migrants and established local residents in local schools and sports clubs, as well as crossover patronage of some migrant businesses. Yet some interviewees expressed concerns about the depth of this engagement, as one illustrated with reference to Irish women visiting a Brazilian nail salon in Gort:

The Irish women coming in ... and having their nails done for communions and confirmations, and they were lined up against the wall with their feet up ... but perhaps one or two of the younger Brazilian women working, I would have been aware of their very vulnerable situation and the Irish women getting ready for the big family wedding or the event and having the craic or whatever [were] completely blissfully unaware of the life and the circumstances of that young wee girl polishing their nails. (Community worker, Gort) ${ }^{10}$

In both towns, attempts to construct multi-cultural spaces of interaction in which there is a blending or fusion of Irish and migrant cultures have had mixed success. At the height of the Brazilian diaspora in Gort, the town boasted a bilingual community newsletter and an annual celebration of the Brazilian Quadrhilla festival in the town square that attracted participants from all parts of the community, but these initiatives folded as the Brazilian population decreased. More durable, perhaps, are the parallel institutions, communal spaces and social networks that have been fostered by international migration, again resonating with observations of Latino migration in rural communities

10. Interview by author, October 2015 
in the United States (Nelson and Hiemstra, 2008; Torres et al., 2006) and, maybe also, the experience of domestic in-migration to many rural communities, which has been argued to have fractured the social spaces of villages (Bell, 1994; Salamon, 2003; Woods, 2011b).

\section{Conclusion}

International migration to and from rural regions is an increasingly prominent feature of the emergent global countryside in Europe, yet geographical and sociological research is only starting to understand the complex dynamics of this phenomenon, and its potential to reshape ruralities. The significance of domestic migration as a driver of change in rural communities is well documented in rural studies, but this paper has argued that international migration too is increasingly having a transformational impact in many parts of rural Europe. The 'new rurality' that is emerging as a consequence is hybrid in character, more multicultural, more cosmopolitan, and more connected with the rest of the world economically and socially. This is most evident in those rural localities that have received proportionately the largest volumes of international migrants, places such as Ballyhaunis in Ireland where the transformation is marked by the presence of Polish and Islamic food shops, a mosque, a cricket club, the mix of languages spoken in the street and schoolyard, and so on. Elsewhere, the effects are less explicit, with international migration and domestic migration in conjunction reshaping demands for public services and housing.

Yet, as these observations imply, the impacts of international migration on rural communities are not consistent across localities. This paper has sought to develop a nuanced understanding of this differentiated geography by drawing together evidence from three research projects and distilling both commonalities and divergences. From this discussion a number of conclusions can be posited.

Firstly, conventional concepts of 'migration' are too rigid and linear to fully capture the dynamic and contingent mobility of people within the global countryside, and we need to adopt a relational understanding of how flows of international mobility are temporarily fixed in specific rural localities with social, cultural and economic affects. Secondly, international migrants are not a homogeneous bloc, and variations in motivations, experiences and aspirations can be found even among migrants from the same country in the same destination locality. These variations in turn will influence the experiences and perceptions of migrants, and the impact of international migration on particular places. Thirdly, patterns of international migration and the circumstances of individual migrants are shaped both by structural factors, including geographical proximity, historical and cultural ties, economic conditions and legal frameworks, and by the agency of migrants themselves and of other catalytic actors who can create unexpected opportunities for migrants. Individual agency can therefore fashion the geography of international migration at a local scale in rural areas. Fourthly, international migrants have the potential to contribute to economic development in rural areas, if their skills, training, connections 
and entrepreneurial agency can be effectively harnessed and supported. Yet this potential has not to date been prominently incorporated into regional development strategies. Finally, the transformative capacity of international migration in rural areas is not only economic, but is also social and cultural. Migrants introduce new cultural tastes, consumer goods, traditions and festivals into rural communities, which are inevitably blended and grafted with endogenous cultural practices and resources; but the evidence for the emergence of genuinely hybrid, multi-cultural formations in rural society is limited at best. Instead, the research revisited in this paper supports assertions elsewhere in the literature that international migration more commonly contributes to the production of parallel, overlapping spaces of engagement in rural communities that are inhabited by different cultural groups.

\section{Bibliographical references}

Aguayo, B.E.C. (2008). "Global villages and rural cosmopolitanism: exploring global ruralities”. Globalizations, 5, 541-554. <http://dx.doi.org/10.1080/14747730802500281>

Bayona i Carrasco, J. and Gil-Alonso, F. (2013). "Is foreign immigration the solution to rural depopulation? The case of Catalonia (1996-2009)". Sociologia Ruralis, 53, 26-51. $<$ http://dx.doi.org/10.1111/j.1467-9523.2012.00577.x>

Bell, M. M. (1994). Childerley: Nature and Morality in a Country Village. Chicago: University of Chicago Press.

Benson, M. (2013). "Living the 'real' dream in la France profonde? Lifestyle migration, social distinction and the authenticities of everyday life". Anthropological Quarterly, 86, 501-525. $<$ http://dx.doi.org/10.1353/anq.2013.0031>

Bodvarsson, Ö. and VAN DEN BERG, H. (2003). "The impact of immigration on a local economy: the case of Dawson County, Nebraska". Great Plains Research, 13, 291-309.

Broadway, M. (1994). "Beef stew: cattle, immigrants and established residents in a Kansas and beefpacking town". In: Lamphere, L., Stepick, A. and Grenier, G. (eds.). Newcomers in the Workplace: Immigrants and restructuring of the U.S. economy. Philadelphia: Temple University Press, 25-43.

Camarero, L., Sampedro, R. and Oliva, J. (2012). "Foreigners, neighbours, immigrants: translocal mobilities in rural areas in Spain". In: HedberG, C. and Do Carmo, R. M. (eds.). Translocal Ruralism. Dordrecht: Springer, 143-162.

Chakraborti, N. and Garland, J. (eds.) (2004). Rural Racism. Cullompton: Willan.

Copus, A., Dubois, A. and Hedström, M. (2011). "Expanding horizons: local embeddedness and global engagement among small firms in the European countryside". European Countryside, 3, 164-182. $<$ http://dx.doi.org/10.2478/v10091-012-0002-y>

Cravey, A. J. (1997). "Latina labor and poultry production in rural North Carolina". Southeastern Geographer, 37, 295-300.

DE LIMA, P. (2012). "Boundary crossings: migration, belonging/'un-belonging' in rural Scotland" In: Hedberg, C. and do Carmo, R. M. (eds.). Translocal Ruralism. Dordrecht: Springer, 203-218. 
do Carmo, R. M. and Santos, S. (2012). "Between marginalisation and urbanisation: mobilities and social change in southern Portugal". In: HedberG, C. and Do Carmo, R. M. (eds.). Translocal Ruralism. Dordrecht: Springer, 13-34.

Eimermann, M., Lundmark, M. and Muller, D. (2012). "Exploring Dutch migration to rural Sweden: international counterurbanisation in the EU". Tidjschrift voor Economische en Sociale Geografie, 103, 330-346.

<http://dx.doi.org/10.1111/j.1467-9663.2011.00696.x>

Farrell, M., Mahon, M. and McDonagh, J. (2012). "The Rural as a return migration destination”. European Countryside, 4 (1), 30-43.

<http://dx.doi.org/10.2478/v10091-012-0012-9>

Findlay, A. and McCollum, D. (2013). "Recruitment and employment regimes: migrant labour channels in the UK's rural agribusiness sector, from accession to recession". Journal of Rural Studies, 30, 10-19. <http://dx.doi.org/10.1016/j.jrurstud.2012.11.006>

Fonseca, M. (2008). "New waves of immigration to small towns and rural areas in Portugal”. Population, Space and Place, 14, 525-535. <http://dx.doi.org/10.1002/psp.514>

Gallent, N. and Tewdwr-Jones, M. (2000). Rural Second Homes in Europe. Aldershot: Ashgate.

GärTnER, S. (2016). "New macroeconomic evidence on internal migration in Sweden, 1967-2003”. Regional Studies, 50, 137-153. <http://dx.doi.org/10.1080/00343404.2014.899693>

Halfacree, K. (2008). "To revitalize counterurbanisation research? Recognising an international and fuller picture". Population, Space and Place, 14, 479-495. <http://dx.doi.org/10.1002/psp.501>

- (2012). "Heterolocal identities? Counter-urbanisation, second homes, and rural consumption in the era of mobilities". Population, Space and Place, 18, 209-224. <http://dx.doi.org/10.1002/psp.665>

Healy, C. (2006). "Carnaval do Galway: the Brazilian community in Gort, 19992006". Irish Migration Studies in Latin America. Available at: <http://www.irlandeses.org/healy_gort.htm>.

Hedberg, C., Forsberg, G. and Najib, A. (2012). "When the World Goes Rural: transnational potentials of international migration in rural Swedish labour markets". In: Hedberg, C. and do Carmo, R. M. (eds.). Translocal Ruralism. Dordrecht: Springer, 125-142.

Hedberg, C. and Haandrikman, K. (2014). "Repopulation of the Swedish countryside: globalization by international migration”. Journal of Rural Studies, 34, 128-138. <http://dx.doi.org/10.1016/j.jrurstud.2014.01.005>

Hoggart, K. and Mendoza, C. (1999). "African immigrant workers in Spanish agriculture”. Sociologia Ruralis, 39, 538-562. <http://dx.doi.org/10.1111/1467-9523.00123>

Hubbard, P. (2005). "Inappropriate and incongruous': opposition to asylum centres in the English countryside". Journal of Rural Studies, 21, 3-17. <http://dx.doi.org/10.1016/j.jrurstud.2004.08.004>

Jentsch, B., De Lima, P. and MacDonald, B. (2007). "Migrant workers in rural Scotland: 'Going to the middle of nowhere'". International Journal of Multicultural Societies, 9, 35-53.

Jones, L. and Lever, J. (2014). Migrant workers in Rural Wales and the South Wales Valleys, Wales Rural Observatory. Available at: <www.walesruralobservatory.org.uk>. 
Kairyte, E. (2015). "Greater globalization challenges - lesser rural responses: the case of Alytus County, Lithuania”. In: McDonagh, J., Nienaber, B. and Woods, M. (eds.). Globalization and Europe's Rural Regions. Farnham: Ashgate, 107-124.

Kasimis, C. (2008). "Survival and expansion: migrants in Greek rural regions". Population, Space and Place, 14, 511-524. <http://dx.doi.org/10.1002/psp.513>

Kasimis, C., Papadopoulos, A. and Pappas, C. (2010). "Gaining from rural migrants: migrant employment strategies and socio-economic implications for rural labour markets". Sociologia Ruralis, 50, 258-276. <http://dx.doi.org/10.1111/j.1467-9523.2010.00515.x>

Kasimis C., Papadopoulos A. and Zacopoulou E. (2003). "Migrants in rural Greece”. Sociologia Ruralis, 43, 53-71. <http://dx.doi.org/10.1111/1467-9523.00237>

Kilpatrick, S., Johns, S., Vitartas, P. and Homison, M. (2011). "Mobile skilled workers: making the most of an untapped rural community resource". Journal of Rural Studies, 27, 181-190. <http://dx.doi.org/10.1016/j.jrurstud.2011.01.003>

Kontuly, T. (1998). "Contrasting the counterurbanisation experience in European nations”. In: Boyle, P. and Halfacree, K. (eds.). Migration to Rural Areas. Chichester: Wiley. 61-78.

King, R., Warnes, T. and Williams, A. (2000). Sunset Lives: British retirement migration to the Mediterranean. London: Berg.

LABRIANIDIs, L. and SyKas, T. (2009). "Geographical proximity and immigrant labour in agriculture: Albanian immigrants in the Greek countryside”. Sociologia Ruralis, 49, 394-414. <http://dx.doi.org/10.1111/j.1467-9523.2009.00494.x>

LAMPIČ, B. and MraK, I. (2012). "Globalization and foreign amenity migrants: the case of foreign home owners in the Pomurska region of Slovenia". European Countryside, 4 (1), 44-56.

Lampič, B., Mrak, I. and PotočNik Slavič, I. (2015). “Transformation of rural Slovenia: the Pomurje region in search of new development paths”. In: McDonagh, J., Nienaber, B. and Woods, M. (eds.). Globalization and Europe's Rural Regions. Farnham: Ashgate, 125-142.

Lolos, S. and Papapetrou, E. (2012). "Regional unemployment and spatial interactions in Greece”. In: Amine, S. (ed.). Labor Markets: Dynamics, Trends and Economic Impact, New York: Nova, 129-145.

Maher, G. (2010). “A transnational migrant circuit: remittances from Ireland to Brazil”. Irish Geography, 43, 177-190. <http://dx.doi.org/10.1080/00750778.2010.500891>

Martarrita-Cascante, D. and Stocks, G. (2013). "Amenity migration to the global south: implications for community development”. Geoforum, 49, 91-102. <http://dx.doi.org/10.1016/j.geoforum.2013.06.004>

Martarrita-Cascante, D., Sene-Harper, A. and Stocks, G. (2015). "International amenity migration: examining environmental behaviours and influence of amenity migrants and local residents in a rural community". Journal of Rural Studies, 38, $1-11$. <http://dx.doi.org/10.1016/j.jrurstud.2015.01.005>

Maza, A. and Villaverde, J. (2004). "Interregional migration in Spain: a semiparametric analysis". Review of Regional Studies, 34, 156-171. 
McAreavey, R. (2012). "Resistance or resilience? Tracking the pathway of recent arrivals to a new rural destination". Sociologia Ruralis, 52, 488-507. <http://dx.doi.org/10.1111/j.1467-9523.2012.00573.x>

McDonagh, J., Nienaber, B. and Woods, M. (eds.) (2015). Globalization and Europe's Rural Regions. Farnham: Ashgate.

McGrath, B. (2010). "Social capital in community, family, and work lives of Brazilian migrant parents in Ireland, Community". Work and Family, 13, 147-165. <http://dx.doi.org/10.1080/13668800903192168>

McGrath, B. and McGarry, O. (2014). "The religio-cultural dimensions of life for young Muslim women in a small Irish town”. Journal of Youth Studies, 17, 948-964. <http://dx.doi.org/10.1080/13676261.2013.878793>

Moss, L. (ed.) (2006). The Amenity Migrants. Wallingford: CABI.

Mounoud, E. M. and Oudinet, J. (2010). "Inequality and migration: what different European patterns of migration tell us". International Review of Applied Economics, 24, 405-422. <http://dx.doi.org/10.1080/02692171003701628>

Mountz, A. and Wright, R. (1996). "Daily life in the transnational migrant community of San Agustin, Oaxaca and Poughkeepsie, New York". Diaspora, 5, 403-427.

Murdoch, J. and Marsden, T. (1994). Reconstituting Rurality. London: UCL Press.

NADLER, R. (2012). "Should I stay or should I go? International migrants in the rural town of Zittau, Saxony and their potential impact on regional development". European Countryside, 4 (1), 57-72. <http://dx.doi.org/10.2478/v10091-012-0014-7>

Neal, S. (2009). Rural Identities: Ethnicity and Community in the English Countryside. Farnham: Ashgate.

Nelson, L. and Hiemstra, N. (2008). "Latino immigrants and the renegotiation of place and belonging in small town America". Social and Cultural Geography, 9, 319-342. <http://dx.doi.org/10.1080/14649360801990538>

Nelson, L. and Nelson, P. (2011). "The global rural: gentrification and linked migration in the rural USA". Progress in Human Geography, 35, 441-459. <http://dx.doi.org/10.1177/0309132510380487>

Nienaber, B. and Frys, W. (2012). "International labour migration in European rural regions: the example of Saarland, Germany". European Countryside, 4 (1), 73-88. <http://dx.doi.org/10.2478/v10091-012-0015-6>

Nienaber, B. and Frys, V. (2015). "The rural regions of the old-industrialized Saarland - between globalization and regionalization". In: McDonagh, J., Nienaber, B. and Woods, M. (eds.). Globalization and Europe's Rural Regions. Farnham: Ashgate, 165-182.

Ní LaOIRE, C. (2007). “The 'green, green, grass of home'? Return migration to rural Ireland”. Journal of Rural Studies, 23, 322-344. <http://dx.doi.org/10.1016/j.jrurstud.2007.01.005>

Papadopoulos, A. (2012). "Transnational immigration in rural Greece: analysing the different mobilities of Albanian immigrants". In: Hedberg, C. and do Carmo, R. M. (eds.). Translocal Ruralism. Dordrecht: Springer, 163-184.

RaINer, G. (2016). "Constructing globalised spaces of tourism and leisure: political ecologies of the Salta Wine Route (NW Argentina)". Journal of Rural Studies, 43, 104-117. <http://dx.doi.org/10.1016/j.jrurstud.2015.11.007> 
Rogaly, B. (2008). "Intensification of workplace regimes in British horticulture: the role of migrant workers". Population, Space and Place, 14, 497-510. <http://dx.doi.org/10.1002/psp.502>

Rye, J. F. and Andrzejewska, J. (2009). "The structural disempowerment of Eastern European migrant farm workers in Norwegian agriculture". Journal of Rural Studies, 26, 41-51. <http://dx.doi.org/10.1016/j.jrurstud.2009.06.003>

Salamon, S. (2003). Newcomers to Old Towns: Suburbanization of the Heartland. Chicago: University of Chicago Press.

Sсотт, S. (2015). "Making the case for temporary migrant worker programmes: evidence from the UK's rural guestworker (SAWS) scheme". Journal of Rural Studies, 40, 1-11. <http://dx.doi.org/10.1016/j.jrurstud.2015.05.005>

Sheringham, O. (2009). "Ethnic identity and integration among Brazilians in Gort, Ireland" Irish Migration Studies in Latin America, 7. Available at: <http://www. irlandeses.org/0903sheringham.htm >.

- (2010). "A Transnational Space? Transnational Practices, Place-Based Identity and the Making of 'Home' among Brazilians in Gort”. Portuguese Studies, 26, 60-78.

SkaptadótTir, U. D. and Wojtynska, A. (2008). "Labour migrants negotiating places and engagements”. In: Bærenholdt, J. O. and Granås, B. (eds.). Mobility and Place: Enacting Northern European Peripheries. Aldershot: Ashgate, 115-126.

Smith, H. and Furuseth, O. (eds.). Latinos in the New South. Aldershot: Ashgate.

Stenbacka, S. (2012). "The rural' intervening in the lives of internal and international migrants: migrants, biographies and translocal practices”. In: HedberG, C. and do Carmo, R. M. (eds.). Translocal Ruralism. Dordrecht: Springer, 55-72.

Stockdale, A. (2006). "Migration: pre-requisite for rural economic development?". Journal of Rural Studies, 22, 354-366. <http://dx.doi.org/10.1016/j.jrurstud.2005.11.001>

Torres, R. M., Popke, E. J. and Hapke, H. M. (2006). "The South's Silent Bargain: Rural reconstructing, Latino labour and the ambiguities of migrant experience". In: Smith, H. and Furuseth, O. (eds.). Latinos in the New South. Burlington, VT: Ashgate, 37-68.

Truly, D. (2002). "International retirement migration and tourism along the Lake Chapala Riviera: developing a matrix of retirement migration behaviour". Tourism Geographies, 4, 261-281. <http://dx.doi.org/10.1080/14616680210147427>

Warnes, A. and Williams, A. (2006). "Older migrants in Europe: a new focus for migration studies". Journal of Ethnic and Migration Studies, 32, 1257-1281. <http://dx.doi.org/10.1080/13691830600927617>

Winders, J. (2007). "Bringing back the (B)order: Post-9/11 politics of immigration, borders, and belonging in the contemporary U.S. South”. Antipode, 39, 920-942.

- (2012). "Seeing immigrants: institutional visibility and immigrant incorporations in new immigrant destinations". Annals of the American Academy of Political and Social Science, 641, 79-98. <http://dx.doi.org/10.1177/0002716211432281>

Woods, M. (2005a). Rural Geography. London and Thousand Oaks: Sage.

- (2005b). Contesting Rurality: Politics in the British Countryside. Aldershot: Ashgate.

- (2009). "Political economies of place in the emergent global countryside: stories from rural Wales". In: Halseth, G., Markey, S. and Bruce D. (eds.). The Next Rural Economies. Wallingford: CAB International, 168-178. 
- (2011a). "Poles apart? Migrant workers in rural Wales". In: Mitbourne, P. (ed.). Rural Wales in the Twenty-first Century. Cardiff: University of Wales Press, 109-125.

- (2011b). Rural. Oxford and New York: Routledge.

- (forthcoming). "Precarious rural cosmopolitanism and neoliberal globalization in Irish small towns". Journal of Rural Studies, forthcoming.

Woods, M. and Watkin, S. (2008). Migrant Workers in Rural Wales. Aberystwyth and Cardiff: Wales Rural Observatory. Available at: <www.walesruralobservatory. org.uk>.

Zúniga, V. and HernándeZ-León, R. (2006). New Destinations: Mexican Immigration in the United States. New York: Russell Sage Foundation. 